\title{
Turfgrass Establishment from Polymer-coated Seed Under Saline Irrigation
}

\author{
Matteo Serena \\ Department of Plant and Environmental Sciences, New Mexico State \\ University, MSC 3Q, Las Cruces, NM 88003
}

\author{
Bernd Leinauer ${ }^{1}$ \\ Department of Extension Plant Sciences, New Mexico State University, MSC \\ 3AE, P.O. Box 30003, Las Cruces, NM 88003
}

\author{
Rossana Sallenave \\ Extension Animal Sciences and Natural Resources Department, New Mexico \\ State University, MSC 3AE, Las Cruces, NM 88003
}

\author{
Marco Schiavon \\ Department of Plant and Environmental Sciences, New Mexico State \\ University, MSC 3Q, Las Cruces, NM 88003
}

\section{Bernd Maier}

Department of Extension Plant Sciences, New Mexico State University, MSC 3AE, Las Cruces, NM 88003

Additional index words. GDD, ZEBA ${ }^{\circledR}$, cornstarch coating in 2009 and 2010 to investigate the establishment of five turfgrass species ['Barrister' kentucky bluegrass [Poa pratensis L.], 'Barvado' tall fescue [Festuca arundinacea Schreb.], 'Premier II' perennial ryegrass [Lolium perenne L.], 'Bargusto' bermudagrass [Cynodon dactylon (L.) Pers. $\times$ Cynodon. transvalensis Burtt-Davy], and 'Sea Spray' seashore paspalum [Paspalum vaginatum $\mathbf{O}$. Swartz] $\}$ from coated and uncoated seed. The grasses were irrigated at $100 \%$ reference evapotranspiration $\left(\mathbf{E T}_{0}\right)$ during fall, winter, and spring and at $120 \% \mathrm{ET}_{0}$ during summer with either saline [electrical conductivity

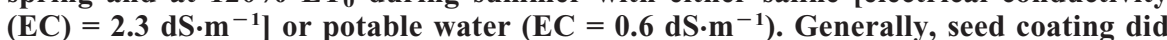
not affect seedling emergence negatively when irrigated with saline water. During fall, perennial ryegrass exhibited fastest emergence under both saline and potable irrigation and bermudagrass was the only grass to show greater emergence when irrigated with saline water. Perennial ryegrass and tall fescue were the fastest to emerge in spring, regardless of seed coating or water quality. Seed coating delayed early establishment (less than $\mathbf{5 0 \%}$ coverage) but did not affect days to reach 95\% coverage (DAS95). Bermudagrass and seashore paspalum required the most DAS95 when seeded in the fall; however, bermudagrass needed fewest DAS95 when seeded in the spring. All grasses established faster when seeded in spring compared with fall. Fall-seeded perennial ryegrass and kentucky bluegrass required similar DAS95, whereas kentucky bluegrass seeded in spring was slower to reach $\mathbf{9 5 \%}$ coverage than perennial ryegrass. Saline water had no effect on establishment when grasses were sown in fall. Surprisingly, grasses established in spring and irrigated with saline water reached $95 \%$ coverage 26 days faster than plots irrigated with potable water. Moreover, the growing degree-day model used in this study did not produce similar values for the different air temperatures and irrigation water qualities.

\footnotetext{
Received for publication 19 Sept. 2012. Accepted for publication 16 Oct. 2012.

Financial support for the study was provided by New Mexico State University's Agricultural Experiment Station and by the Office for Facilities and Services, by the Cooperative State Research, Education, and Extension Service, U.S. Department of Agriculture under Agreement No. 2005 34461-15661 and 2005-45049-03209, and by Barenbrug USA.

We are also grateful for the donations from Helena Chemical, Toro Co., and from Scotts Co.

${ }^{1}$ To whom reprint requests should be addressed; e-mail leinauer@nmsu.edu.
}

Soil salinization is a growing problem throughout the world, particularly in arid and semiarid regions such as the southwestern United States, where saline and/or sodic soils are a common occurrence of irrigated lands. Saline soils can negatively affect both agricultural and landscape plants by impeding germination, establishment, growth, reproduction, and visual quality. Saline soils can be of natural origin or can become saline through the use of poor water quality for irrigation. Landscape and turfgrass irrigation have been identified as sources of high water consumption, are deemed non-essential for human living, and are considered as an unnecessary luxury. For this reason, alternative but saline water sources such as recycled water or low-quality groundwater are becoming increasingly attractive for irrigating recreational turf areas such as parks, athletic fields, and golf courses. In the southwestern United States $37 \%$ of all golf courses are currently irrigated with re-used (effluent or reclaimed) water (Throssell et al., 2009). This type of water is more saline than potable water (Duncan et al., 2009; Harivandi et al., 2008; Huck et al., 2000) and can contain high quantities of detrimental ions such as sodium (Harivandi et al., 2008; Marcum et al., 1998; Suplick-Ploense et al., 2002). This poses a problem for growing and maintaining turfgrasses, especially during the germination and establishment stages (Qian and Suplick, 2001). Capillary rise and evaporation accumulate salts on and near the soil surface, thus bringing a saline solution in contact with the seeds (Almansouri et al., 2001) and turf species can exhibit greater salt stress during establishment than as mature plants (Duncan et al., 2009).

Controlled environment studies (Dudeck and Peacock, 1985; Harivandi et al., 1992) indicate that most of the cool-season grasses, with the exception of perennial ryegrass (Lolium perenne L.) and alkaligrass [Puccinellia distans (Jacq.) Parl.], are sensitive to salinity during germination. Information on the germination of warm-season grasses under saline conditions is limited and what is known indicates a wide range of salinity tolerances among species. For example, bermudagrass [Cynodon dactylon (L.) Pers.] is one of the most tolerant grasses to salinity, whereas bahiagrass (Paspalum notatum Flüggé) is highly sensitive to increases in salinity at the germination stage (Peacock and Dudeck, 1989).

Commercially available turfgrass seeds can be coated with materials intended to increase seed size and improve germination and establishment. Seed coatings are applied to give the seed a suitable shape and size and to add compounds that help and protect germination and establishment of the plant (Scott, 1989). Materials such as hydrophilic polymers have been used as coatings for several years with the purpose to increase moisture around the seed, thereby increasing germination and establishment of plants (Hendrick and Mowry, 1953). However, no such improvement in germination or establishment was observed in a study on lettuce seeds coated with polymers (Sharples, 1981) or in polymercoated Russian wild rye seeds (Berdhal and Barker, 1980). In another study, Baxter and Waters (1986) reported lower germination and establishment of cowpea seeds coated with hydrophilic polymers compared with uncoated seeds, possibly as a result of lower oxygen levels surrounding the coated seeds In 2006, a cornstarch coating was introduced for turfgrass seeds (Arends, 2007), purported to improve seed water retention. The coating consists of a polymer [starch-g-poly (2-propenamide-co-propenoic acid) potassium 
salt], which, according to the manufacturer, absorbs water up to 400 times its own weight (Absorbent Technologies, 2006; Arends, 2007).

Little information is available on the establishment of turfgrasses under saline conditions in general and from coated seed under saline irrigation in particular. Schiavon et al. (2012) found that bermudagrass and seashore paspalum successfully established from seed in one growing season when moderately saline irrigation water $\left(\mathrm{EC}=2.3 \mathrm{dS} \cdot \mathrm{cm}^{-1}\right)$ was applied. However, information is lacking on the establishment of more salt-sensitive cool-season species such as kentucky bluegrass, tall fescue, and perennial ryegrass. Leinauer et al. (2010) reported that seed coating improved establishment of both warmand cool-season turfgrasses grown under unfavorable conditions such as low seeding rates or deficit irrigation. More information is needed to determine the effect of hydrophilic coatings on the emergence and establishment of turfgrasses under saline irrigation in the field. Increased water content around a coated seed could result in greater exposure to salinity, which in turn could decrease emergence and reduce speed of establishment. The objective of our study was to investigate the effects of a hydrophilic seed coating material $\left(\mathrm{ZEBA}^{\circledR}\right)$ on seed emergence and establishment of cool- and warm-season turfgrasses seeded either in the fall or spring and irrigated with potable or saline water.

\section{Materials and Methods}

A field experiment was conducted at New Mexico State University's Turfgrass Salinity Research Center in Las Cruces (arid, 1265 m elevation; USDA plant hardiness zone 8) from Sept. 2009 to Sept. 2010 to investigate the effect of water quality and ZEBA ${ }^{\circledR}$ polymer seed coating (Absorbent Technologies, Beaverton, OR) on emergence and establishment of cool- and warm-season turfgrasses. Monthly average temperatures, $\mathrm{ET}_{0}$, and precipitation during the investigative period are listed in Table 1; daily precipitation is shown in Figure 1. The experimental design was a randomized complete block with water quality as whole block, turfgrasses and seeding date as whole plot $(5 \times 2$ factorial $)$, and seed

Table 1 . Monthly average air temperature $\left({ }^{\circ} \mathrm{C}\right)$, soil temperature (soil temp.) at $10 \mathrm{~cm}\left({ }^{\circ} \mathrm{C}\right)$, precipitation $(\mathrm{mm})$, and reference evapotranspiration $\left(\mathrm{ET}_{0}, \mathrm{~mm}\right)$ for the study site during the research period (Sept. 2009 to Sept. 2010).

\begin{tabular}{|c|c|c|c|c|c|c|c|}
\hline \multirow[b]{2}{*}{$\mathrm{Yr}$} & \multirow[b]{2}{*}{ Month } & \multicolumn{3}{|c|}{ Air temp. $\left({ }^{\circ} \mathrm{C}\right)$} & \multirow{2}{*}{$\begin{array}{l}\text { Soil temp. } \\
\left({ }^{\circ} \mathrm{C}\right)\end{array}$} & \multirow{2}{*}{$\begin{array}{l}\text { Precipitation } \\
(\mathrm{mm})\end{array}$} & \multirow{2}{*}{$\begin{array}{l}\mathrm{ET}_{0} \\
(\mathrm{~mm})\end{array}$} \\
\hline & & $\overline{A v g}$ & Maximum & $\overline{\text { Minimum }}$ & & & \\
\hline \multirow[t]{4}{*}{2009} & September & 23.2 & 30.3 & 16.1 & 23.5 & 35 & 141 \\
\hline & October & 17.5 & 25.0 & 10.4 & 18.7 & 8 & 103 \\
\hline & November & 11.8 & 20.7 & 3.6 & 12.2 & 43 & 73 \\
\hline & December & 5.5 & 12.7 & -0.7 & 8.6 & 17 & 45 \\
\hline \multirow[t]{9}{*}{2010} & January & 5.4 & 13.4 & -1.2 & 8.4 & 26 & 53 \\
\hline & February & 8.3 & 15.5 & 1.7 & 10.5 & 10 & 63 \\
\hline & March & 11.6 & 20.1 & 2.7 & 12.2 & 0 & 109 \\
\hline & April & 17.1 & 25.0 & 8.5 & 16.6 & 4 & 143 \\
\hline & May & 22.3 & 30.6 & 12.3 & 19.0 & 0 & 194 \\
\hline & June & 28.2 & 36.4 & 19.1 & 23.1 & 14 & 219 \\
\hline & July & 27.1 & 33.9 & 20.9 & 25.2 & 71 & 192 \\
\hline & August & 27.4 & 34.7 & 20.6 & 25.6 & 34 & 187 \\
\hline & September & 24.8 & 32.0 & 17.7 & 23.2 & 43 & 147 \\
\hline
\end{tabular}

coating as a split plot. Each individual whole plot measured $1.5 \mathrm{~m} \times 2.0 \mathrm{~m}$ and all treatment factors were replicated three times.

The soil at the site consisted of a sandy loam, a sandy skeletal mixed thermic Typic Torriorthent, an entisol typical for arid regions. The research area was converted from desert vegetation to turfgrass test plots in 2007 and main blocks had been irrigated with either potable or saline water for two years before the study. Therefore, salinity values [EC and sodium adsorption ratio (SAR)] of the root zone at depths of 0 to $10 \mathrm{~cm}$ in plots irrigated with saline water were slightly higher at seeding date than in plots irrigated with potable water (Table 2). However, soil salinity at seeding did not exhibit levels that would inhibit germination of tested grass seed (Serena et al., 2012). Grasses included kentucky bluegrass 'Barrister' (Poa pratensis L.), tall fescue 'Barvado' (Festuca arundinacea Schreb.), perennial ryegrass 'Premier II' (Lolium perenne L.), bermudagrass 'Bargusto' [Cynodon dactylon (L.) Pers. $\times$ Cynodon. transvalensis Burtt-Davy], and seashore paspalum 'Sea Spray' (Paspalum vaginatum O. Swartz). Treatments included ZEBA ${ }^{\circledR}$-coated and uncoated seed. Plots were irrigated with either saline $\left(\mathrm{EC}=2.3 \mathrm{dS} \cdot \mathrm{m}^{-1}\right)$ or potable water $\left(\mathrm{EC}=0.6 \mathrm{dS} \cdot \mathrm{m}^{-1}\right)$. Saline water originated from a shallow saline aquifer and was pumped to the research site. The saline water is classified as high in salinity and medium for sodium hazard (C3-S2) (U.S. Salinity Laboratory Staff, 1954) and matches the salinity of recycled water used for turf irrigation in the Southwest (Duncan et al., 2009; Huck et al., 2000). Chemical constituents in the irrigation water are listed in Table 3. Irrigation was applied by means of a sprinkler system comprising T5 Rotors (The Toro Company, Riverside, CA) installed in each corner of a $10 \mathrm{~m} \times 10 \mathrm{~m}$ block and operated at $275 \mathrm{kPa}$. Irrigation amounts were calculated every Monday morning based on the previous

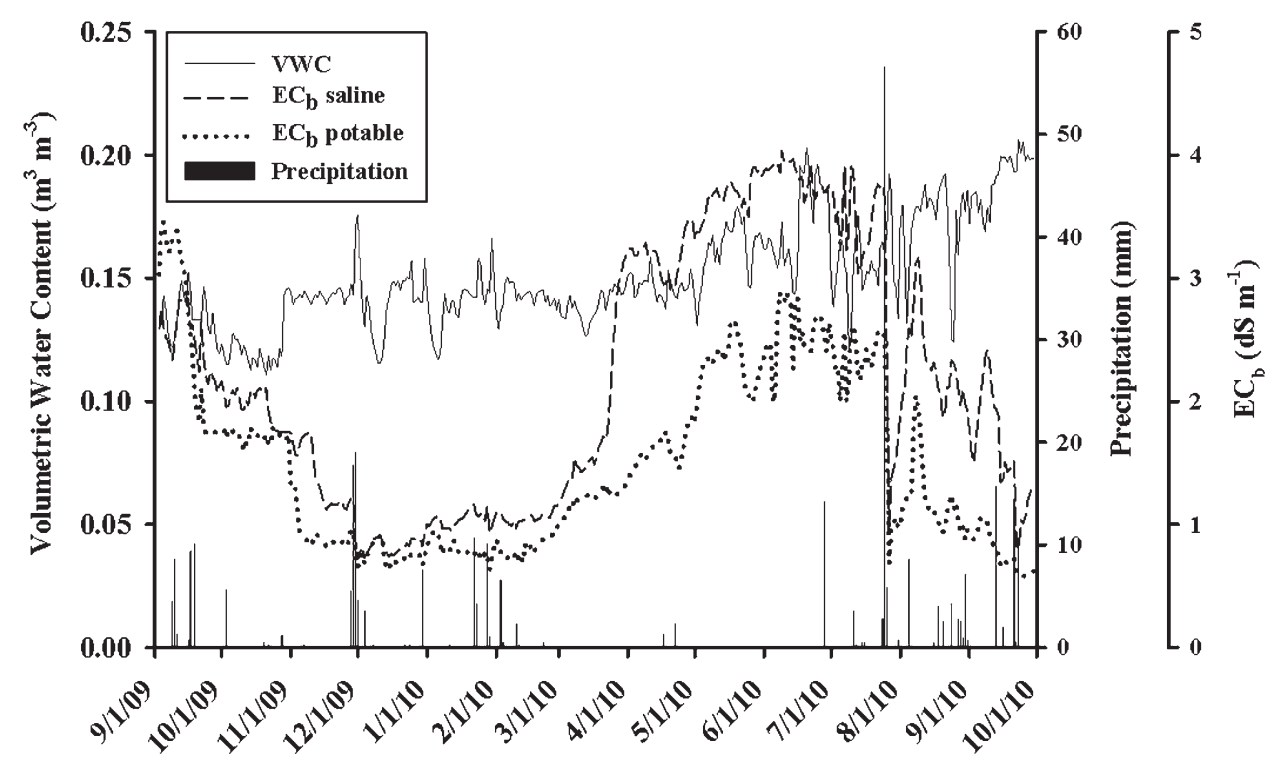

Fig. 1. Volumetric water content $\left(\mathrm{VWC}, \mathrm{m}^{3} \cdot \mathrm{m}^{-3}\right)$ and bulk electrical conductivity $\left(\mathrm{EC}_{\mathrm{b}}, \mathrm{dS} \cdot \mathrm{m}^{-1}\right)$ in soil irrigated with potable or saline water at $10 \mathrm{~cm}$ depth and natural precipitation $(\mathrm{mm})$ from Sept. 2009 to Oct. 2010. 
week's cumulative $\mathrm{ET}_{0}$ rate (Allen et al., 2005), and plots received a daily equivalent of one-seventh of the total weekly $\mathrm{ET}_{0}$. Air temperature $\left({ }^{\circ} \mathrm{C}\right)$ and other climate data to calculate $\mathrm{ET}_{0}$ were collected from a weather station located at the site. Frequent audits provided information regarding irrigation uniformity and information on the amount of water distributed to each block. Sprinkler delivery rates were subsequently used to calculate irrigation run times. Plots were irrigated at $100 \% \mathrm{ET}_{0}$ during fall, winter, and spring and at $120 \% \mathrm{ET}_{0}$ during the summer months.

Toro Turf Guard sensors (The Toro Company, Bloomington, $\mathrm{MN}$ ) placed at $10-\mathrm{cm}$ soil depth (NOAA, 1989) were used to collect volumetric water content and bulk EC $\left(\mathrm{EC}_{\mathrm{b}}\right)$ data. Soil moisture and $\mathrm{EC}_{\mathrm{b}}$ data were collected every $7 \mathrm{~min}$ and averaged over $1 \mathrm{~d}$ from day of planting to the end of establishment. Growing degree-days (GDDs) were calculated using the Baskerville-Emin equation (Baskerville and Emin, 1969). A base temperature of $5^{\circ} \mathrm{C}$ was chosen for warm-season seashore paspalum and bermudagrass (Unruh et al., 1996), and $10^{\circ} \mathrm{C}$ was considered appropriate for all the cool-season grasses (Branham and Danneberger, 1989).

Grasses were seeded on 3 Sept. 2009 and on 15 Mar. 2010. Before seeding, main blocks were rototilled and hand-raked to achieve a level and uniform seed bed and Milorganite ${ }^{\circledR}$ organic fertilizer (Milorganite, Milwaukee, WI) was applied at a rate of $2.5 \mathrm{~g} \mathrm{~N} / \mathrm{m}^{2}$. After fertilizing and seeding, plots were again hand-raked several times from different directions to cover the seed with soil. Grasses were seeded at the manufacturers' recommended rates for uncoated seeds and are based on Pure Live Seed. Seeding rate for coated seeds was adjusted to match seed number of uncoated seed (Table 4). Seed emergence was assessed visually $30 \mathrm{~d}$ after seeding (DAS), on 3 Oct. 2009 on plots seeded in fall, and on 14 Apr. 2010 on plots seeded in spring. Germination ratings were taken across the entire split plot on a scale of 0 to $3(0=$ no emergence to $3=$ complete emergence) (Leinauer et al., 2010). During establishment plots were fertilized monthly at a rate of $5 \mathrm{~g} \mathrm{~N} / \mathrm{m}^{2}$ from a complete $15 \mathrm{~N}-15 \mathrm{P}-15 \mathrm{~K}$ fertilizer. Plots were mowed weekly at $5 \mathrm{~cm}$ height starting on 29 Mar. 2010 for the plots seeded on Fall 2009 and on 24 May 2010 for the plots seeded on Spring 2010. Weeds were removed manually throughout the research period.

Turfgrass establishment was assessed by digital image analysis. Beginning on 23 Nov. 2009 for the fall seeding and on 10 May 2010 for the spring-seeded plots, two digital images were taken of each plot every $14 \mathrm{~d}$. Images were taken using a Canon A570is (Canon Inc., Tokyo, Japan) camera housed in a light box equipped with four 9-W lamps to provide equal and uniform lighting conditions (Ikemura, 2003). Turf coverage was determined from the digital images using SigmaScan ${ }^{\circledR}$ Pro 5 (Systat Software Inc., San Jose, CA) following methods described by

Table 2. Rootzone salinity values [electrical conductivity $\left(\mathrm{EC}, \mathrm{dS} \cdot \mathrm{m}^{-1}\right)$ and sodium adsorption ration (SAR)] at soil depths of 0 to $10 \mathrm{~cm}$ in plots irrigated with either saline or potable water. ${ }^{\mathrm{z}}$

\begin{tabular}{|c|c|c|c|c|c|c|c|c|}
\hline \multirow[b]{2}{*}{ Water quality } & \multicolumn{2}{|c|}{ Sept. 2009} & \multicolumn{2}{|c|}{ Feb. 2010} & \multicolumn{2}{|c|}{ June 2010} & \multicolumn{2}{|c|}{ Sept. 2010} \\
\hline & $\overline{\mathrm{EC}}$ & SAR & $\overline{\mathrm{EC}}$ & SAR & $\overline{\mathrm{EC}}$ & SAR & EC & SAR \\
\hline Potable & 0.56 & 1.42 & 0.52 & 1.57 & 0.89 & 2.93 & 0.69 & 0.90 \\
\hline Saline & 0.78 & 1.56 & 0.84 & 2.27 & 2.24 & 6.42 & 1.24 & 0.86 \\
\hline
\end{tabular}

${ }^{2}$ Soil samples were collected before seeding (Sept. 2009 and Feb. 2010), in June 2010, and at the end of the establishment period (Sept. 2010).

Richardson et al. (2001). Total coverage of each plot was based on the mean value obtained from the two digital images.

A scatterplot of percent coverage vs. DAS revealed a non-linear relationship between the two variables. A sigmoidal association (Busey and Myers, 1979; Leinauer et al., 2010; Schiavon et al., 2012) was found to best describe establishment of the turf plots. With this model, establishment begins at zero, increases first slowly, then rapidly, and progresses asymptotically toward a maximum cover. Establishment was considered successful when $95 \%$ cover was reached. Sigmoidal models were subsequently used to calculate DAS and GDD needed to reach $50 \%$ and $95 \%$ of green cover for each replicate separately. All data were subjected to analysis of variance using SAS Proc Mixed (SAS Institute, Inc., Cary, NC) followed by multiple comparison of means using Fisher's protected least significant difference at the probability level of 0.05 .

\section{Results and Discussion}

Emergence. Initial analysis of seedling emergence data revealed a significant fourway interaction among coating treatment, grass species, water quality, and seeding date (data not shown). Results were subsequently reanalyzed separately for each seeding date (Table 5). Neither seed coating nor any of the interactions between coating and the other treatments significantly affected seedling emergence when grasses were seeded in the fall (Table 5). However, a significant interaction between water quality and grasses was detected for fall-seeded grasses. For grasses seeded in spring, seedling emergence was affected by an interaction among grasses, water quality, and seed coating (Table 5).

Of all the grasses seeded in the fall, Bargusto bermudagrass exhibited greater emergence under saline irrigation than under potable water (Table 6). Water quality did not affect seedling emergence in any of the other grasses (Table 6). These results support findings of Johnson et al. (2007) and Serena et al. (2012), who reported that final germination of turfgrasses was not reduced by irrigation salinity values of 2.2 and $3.0 \mathrm{dS} \cdot \mathrm{m}^{-1}$.

Generally, when grasses were seeded in spring under saline irrigation, coating did not negatively affect seedling emergence. In fact, perennial ryegrass emergence from coated seed was greater than from uncoated (Table 6). Serena et al. (2010) also documented higher germination rates for coated vs. uncoated perennial ryegrass when seeds
Table 3. Main chemical constituents of potable and saline water used in the study.

\begin{tabular}{lcr}
\hline & \multicolumn{2}{c}{ Water quality } \\
\cline { 2 - 3 } Main constituents & Potable & Saline \\
\hline Electrical conductivity $\left(\mathrm{dS} \cdot \mathrm{m}^{-1}\right)$ & 0.6 & 2.3 \\
$\mathrm{pH}$ & 7.6 & 7.7 \\
Bicarbonate $\left(\mathrm{meq} \cdot \mathrm{L}^{-1}\right)$ & 2.7 & 2.9 \\
Calcium $\left(\mathrm{meq} \cdot \mathrm{L}^{-1}\right)$ & 2.8 & 7.4 \\
Sodium $\left(\mathrm{meq} \cdot \mathrm{L}^{-1}\right)$ & 2.5 & 12.5 \\
Sodium adsorption ratio & 1.9 & 5.6 \\
\hline
\end{tabular}

Table 4. Seeding rates $\left(\mathrm{g} \cdot \mathrm{m}^{-2}\right)$ for coated and uncoated seed and number of seed $/ \mathrm{m}^{2}$ of grasses used in the study.

\begin{tabular}{lrrr}
\hline & \multicolumn{2}{c}{ Uncoated } & Coated \\
\cline { 2 - 3 } Grass species & \multicolumn{2}{c}{ Seed $\left(\mathrm{g} \cdot \mathrm{m}^{-2}\right)$} & Seed $/ \mathrm{m}^{2}$ \\
\hline Bermudagrass & 9.8 & 20.0 & 45,500 \\
Seashore paspalum & 4.9 & 10.6 & 8,600 \\
Kentucky bluegrass & 9.8 & 21.2 & 31,600 \\
Tall fescue & 39.1 & 87.1 & 18,600 \\
Perennial ryegrass & 29.4 & 70.4 & 20,500 \\
\hline
\end{tabular}

were exposed to water with $2.2 \mathrm{dS} \cdot \mathrm{m}^{-1}$ of salinity. All other grasses showed no difference in emergence between coated seeds combined with saline irrigation and coated seeds irrigated with potable water (Table 6). Warm-season bermudagrass and seashore paspalum emerged 30 DAS in fall but not in spring (Table 6). This can be explained by higher soil temperatures in September compared with March and April (Table 1), which promoted rapid seed emergence in fall but not in spring. Of the cool-season grasses tested, more perennial ryegrass and tall fescue seedlings emerged 30 DAS than did kentucky bluegrass seedlings for both seeding dates (Table 6). Under potable irrigation, coated tall fescue seeds exhibited greater emergence and coated perennial ryegrass seeds had lower emergence compared with their uncoated counterparts. Coating had no effect on emergence of kentucky bluegrass. These results support those of Leinauer et al. (2010) who reported no difference in emergence between coated and uncoated seed in either kentucky bluegrass or tall fescue under two deficit irrigation treatments. However, results vary among different germination and emergence studies. Richardson and Hignight (2010) found no difference in emergence between coated and uncoated tall fescue but greater emergence for coated kentucky bluegrass when potable water was used for establishment. Zhang et al. (2011) found greater germination in coated bluegrass seeds when saline water was used, whereas Serena et al. (2012) documented a negative effect of 
a coating treatment on the germination of kentucky bluegrass. These conflicting findings indicate that there is no consistent trend in the effect of seed coating on germination or seedling emergence in grasses. Moreover, comparing controlled environment tests (Serena et al., 2012; Zhang et al., 2011) with our field emergence results indicates that results obtained from growth chamber or greenhouse germination experiments are not always good predictors of seedling emergence in the field.

Establishment. As concluded in other studies (Busey and Myers, 1979; Leinauer et al., 2010; Schiavon et al., 2012), we found that a sigmoidal model best described establishment of the cool- and warm-season grasses tested. When percent groundcover was plotted against DAS, the coefficients of determination for each replicate ranged from 0.94 to 1 for fall seeding and from 0.89 to 1 for spring seeding. Analysis of variance revealed that the interaction between grass species and seeding date significantly affected DAS50 and DAS95 (Table 5). Seed coating had a significant effect on DAS50 but not on DAS95 (Table 5). Moreover, the interaction between seeding date and water quality was significant for DAS95 but not for DAS50 (Table 5).

Grasses differed in the number of days required to reach $50 \%$ and $95 \%$ coverage on both seeding dates. Among all grasses established during Fall 2009, bermudagrass and seashore paspalum required the greatest number of DAS to reach both $50 \%$ and $95 \%$ of coverage (Fig. 2). When seeded in the fall, tall fescue and kentucky bluegrass needed a similar number of DAS50; however, kentucky bluegrass reached $95 \%$ coverage faster than tall fescue. These results differ from those of St. John et al. (2009) who reported that establishment of kentucky bluegrass was slower than that of tall fescue when seeded in the fall. Perennial ryegrass needed the fewest DAS50, but DAS95 was not different from those needed by kentucky bluegrass (Fig. 2). Loschinkohl and Boehm (2001) also found no difference in groundcover between perennial ryegrass and kentucky bluegrass when established from seed in the fall. In contrast, Newell (1997) reported that perennial ryegrass seeded in November was the fastest grass to establish among several cool-season grasses. Spring-seeded perennial ryegrass also needed the fewest number of DAS50 but reached $95 \%$ coverage within a similar number of days as tall fescue (Fig. 2).

Fall seeding of bermudagrass and seashore paspalum was applied too early to be considered dormant seeding (Schiavon et al., 2012; Shaver et al., 2006). Seed emergence was observed 30 DAS and seedlings were unaffected by winter temperatures because establishment resumed in the spring. Fallseeded bermudagrass and seashore paspalum reached $95 \%$ coverage at the same time (end of July). Seashore paspalum required 24 more days to reach $95 \%$ coverage than bermudagrass when seeded in spring. These results are different from Schiavon et al. (2012) and Serena et al. (2008) who found
Table 5. Results of analysis of variance testing the effects of water quality, grasses, seed coating, and their interactions on seed emergence and days after seeding (DAS) and growing degree-days (GDD) to reach $50 \%$ (DAS50, GDD50) and 95\% (DAS95, GDD95) of ground coverage. ${ }^{\mathrm{z}}$

\begin{tabular}{|c|c|c|c|c|c|c|}
\hline \multirow[b]{2}{*}{ Effect } & \multicolumn{2}{|c|}{ Emergence } & \multicolumn{4}{|c|}{ Groundcover } \\
\hline & Fall & $\overline{\text { Spring }}$ & $\overline{\text { DAS50 }}$ & DAS95 & GDD50 & $\overline{\text { GDD95 }}$ \\
\hline$\overline{\text { Water quality (W) }}$ & NS & NS & NS & * & NS & * \\
\hline Grass (G) & $* * *$ & $* * *$ & $* * *$ & $* * *$ & $* * *$ & $* * *$ \\
\hline $\mathrm{W}^{*} \mathrm{G}$ & $* * *$ & NS & NS & NS & $* *$ & NS \\
\hline Coating (C) & NS & NS & $* * *$ & NS & $* * *$ & NS \\
\hline $\mathrm{C} * \mathrm{~W}$ & NS & NS & NS & NS & NS & NS \\
\hline $\mathrm{C} * \mathrm{G}$ & NS & NS & NS & NS & $* * *$ & NS \\
\hline $\mathrm{C} * \mathrm{~W} * \mathrm{G}$ & NS & $*$ & NS & NS & NS & NS \\
\hline Seeding date (S) & & & $* * *$ & $* * *$ & $* * *$ & * \\
\hline $\mathrm{S} * \mathrm{~W}$ & & & NS & $*$ & NS & $*$ \\
\hline $\mathrm{S}^{*} \mathrm{C}$ & & & NS & NS & NS & NS \\
\hline $\mathrm{S}^{*} \mathrm{~W}^{*} \mathrm{C}$ & & & NS & NS & NS & NS \\
\hline $\mathrm{S}^{*} \mathrm{G}$ & & & $* * *$ & $* * *$ & $* * *$ & $* * *$ \\
\hline $\mathrm{S}^{*} \mathrm{G}^{*} \mathrm{~W}$ & & & NS & NS & NS & NS \\
\hline $\mathrm{S} * \mathrm{G}^{*} \mathrm{C}$ & & & NS & NS & NS & NS \\
\hline $\mathrm{S}^{*} \mathrm{~W}^{*} \mathrm{G}^{*} \mathrm{C}$ & & & NS & NS & NS & NS \\
\hline
\end{tabular}

${ }^{\mathrm{z} E m e r g e n c e}$ data were analyzed separately for fall and spring seeding; therefore, no analysis of variance results including seeding date are presented.

* Significant $\mathrm{F}$ test at the 0.05 level of probability.

** Significant $\mathrm{F}$ test at the 0.01 level of probability.

***Significant $\mathrm{F}$ test at the 0.001 level of probability.

NS $=$ Nonsignificant at the $0.05 P$ level.

Table 6. Turfgrass emergence (on a scale of 0 to 3 with $0=$ no emergence and $3=$ visible emergence across the entire plot) $30 \mathrm{~d}$ after seeding of turfgrasses seeded either in fall or in spring. ${ }^{\mathrm{z}}$

\begin{tabular}{|c|c|c|c|c|c|c|}
\hline \multirow[b]{3}{*}{ Grass species } & & & \multicolumn{4}{|c|}{ Spring seeding } \\
\hline & \multicolumn{2}{|c|}{ Fall seeding } & \multicolumn{2}{|c|}{ Potable } & \multicolumn{2}{|c|}{ Saline } \\
\hline & Potable & Saline & Uncoated & Coated & Uncoated & Coated \\
\hline Bermudagrass & $1.0 \mathrm{e}^{\mathrm{y}}$ & $2.0 \mathrm{~d}$ & $0.0 \mathrm{e}$ & $0.0 \mathrm{e}$ & $0.0 \mathrm{e}$ & $0.0 \mathrm{e}$ \\
\hline Seashore paspalum & $1.0 \mathrm{e}$ & $1.0 \mathrm{e}$ & $0.0 \mathrm{e}$ & $0.0 \mathrm{e}$ & $0.0 \mathrm{e}$ & $0.0 \mathrm{e}$ \\
\hline Kentucky bluegrass & $1.0 \mathrm{e}$ & $0.8 \mathrm{e}$ & $1.3 \mathrm{~d}$ & $1.0 \mathrm{~d}$ & $1.0 \mathrm{~d}$ & $1.3 \mathrm{~d}$ \\
\hline Perennial ryegrass & $3.0 \mathrm{a}$ & $2.8 \mathrm{ab}$ & $3.0 \mathrm{a}$ & $2.3 \mathrm{bc}$ & $2.0 \mathrm{c}$ & $2.7 \mathrm{ab}$ \\
\hline Tall Fescue & $2.5 \mathrm{bc}$ & $2.3 \mathrm{~cd}$ & $2.0 \mathrm{c}$ & $2.7 \mathrm{ab}$ & $2.0 \mathrm{c}$ & $2.3 \mathrm{bc}$ \\
\hline
\end{tabular}

${ }^{\mathrm{z} E m e r g e n c e}$ values for fall seeding represent an average of six data points and are pooled over two seed coatings (coated and uncoated) and three replicates. Values for spring seeding represent an average of three replicates.

${ }^{\mathrm{y}}$ Values followed by the same letter (separately for fall and spring seeding) are not significantly different from one another (Fisher's protected least significant difference at $\alpha=0.05$ ).

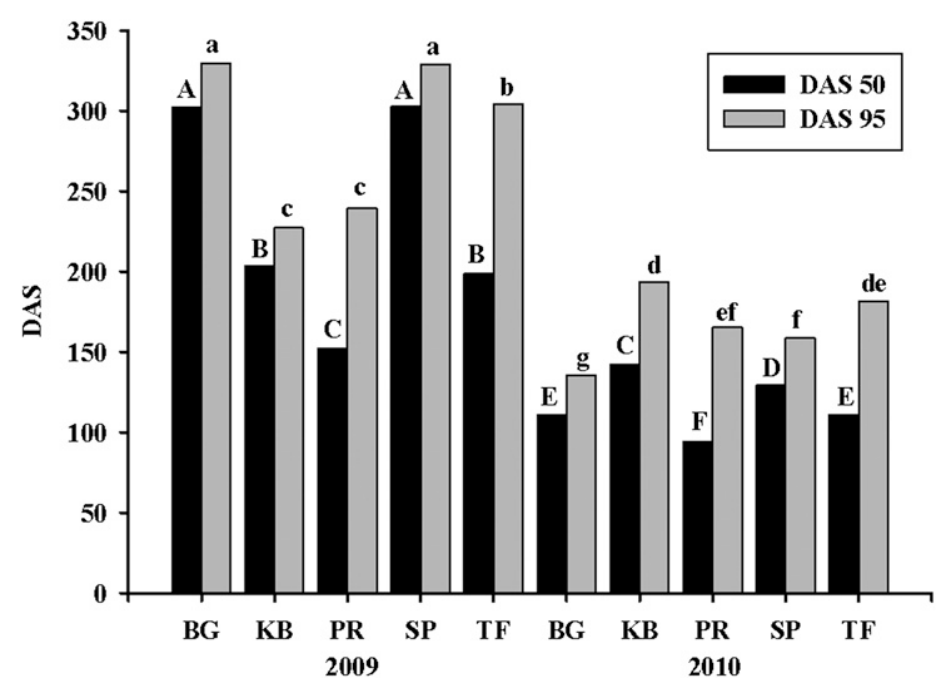

Fig. 2. Days after seeding to reach 50\% (DAS50) and 95\% groundcover (DAS95) of bermudagrass (BG), kentucky bluegrass (KB), perennial ryegrass (PR), seashore paspalum (SP), and tall fescue (TF) seeded either in fall (3 Sept. 2009) or in spring (15 Mar. 2010). Values are averaged over two water qualities [potable $\left(\mathrm{EC}=0.6 \mathrm{dS} \cdot \mathrm{m}^{-1}\right)$ and saline $\left(\mathrm{EC}=2.3 \mathrm{dS} \cdot \mathrm{m}^{-1}\right)$ ], two seed treatments (coated and uncoated), and three replications. Bars followed by the same letters [separately for DAS50 (upper case letters) and DAS95 (lower case letters)] are not significantly from one another (Fisher's protected least significant difference, $\alpha=0.05)$. 
both warm-season grasses establishing equally fast when seeded in spring.

Generally, all species established faster when seeded in spring vs. fall (Fig. 2). Wilhelm et al. (2010) also found that kentucky bluegrass established faster when seeded in spring compared with fall. However, Fiorio et al. (2012) and Reicher et al. (2000) reported faster cool-season establishment in fall compared with spring in transitional-humid and temperate Mediterranean climate zones, respectively. These conflicting results emphasize the need for regional studies to determine optimal seeding dates, because one single optimal seeding date for cool-season grasses does not apply across different climate zones.

In the current study, irrigation with saline water did not increase soil salinity to a level that affected early establishment, which is indicated by a lack of significant water quality main effects or of significant interactions with all other effects on DAS50 (Table 5). The assumption that soil salinity would increase over time when irrigation is applied with saline water was not confirmed during early establishment in fall. Instead, irrigation at $\mathrm{ET}_{0}$ replacement level and several rainfall events resulted in $\mathrm{EC}_{\mathrm{b}}$ decreasing between Sept. 2009 and Feb. 2010 (Table 1; Fig. 1). Moreover, soil chemical analyses conducted on samples taken from a depth of 0 to $10 \mathrm{~cm}$ indicated that $\mathrm{EC}$ values remained unchanged from September to February and SAR increased slightly over the same period (Table 2).

Analyses of variance revealed that the interaction between seeding date and water quality significantly affected DAS95 (Table 5). Saline water did not affect establishment when grasses were sown in fall (Fig. 3). However, plots established in spring and irrigated with saline water reached $95 \%$ coverage $26 \mathrm{~d}$ faster (154 DAS) than plots irrigated with potable water (180 DAS) (Fig. 3). Johnson et al. (2007) and Schiavon et al. (2012) also documented faster establishment of warm-season grasses in spring and summer when saline water was used for irrigation. However, Wilhelm et al. (2010) found that saline irrigation water (EC $3.1 \mathrm{dS} \cdot \mathrm{m}^{-1}$; SAR 2.1 ) negatively affected the establishment of both spring- and fall-seeded kentucky bluegrass. Contrary to the changes of soil salinity during late fall and winter, lack of natural precipitation and increasing irrigation amounts during spring and early summer of 2010 (Table 1) resulted in increasing root zone salinity $\left(E_{b}\right)$ from February to June (Fig. 1). These data are confirmed by soil test results, which also showed higher EC and SAR in June than in February for both potable and salineirrigated plots (Table 2). Highest $\mathrm{EC}_{\mathrm{b}}$ was measured in June (Fig. 1) on plots irrigated with saline water and corresponded with a saturated paste root zone EC and SAR of 2.24 and 6.42 (Table 2). However, these levels had no negative effect on the establishment of the tested warm- and cool-season turfgrasses. These findings are supported by Wilhelm et al. (2010) for tall fescue but not for kentucky bluegrass. The authors reported a soil EC of slightly above 4 and a SAR of $\approx 3$ to have no effect on the establishment of tall fescue but delayed establishment of kentucky bluegrass.

The GDD model used in this study did not account for the differences in air temperature between fall and spring and more research is needed to investigate whether such models can be used to predict establishment over different climatic conditions, different grasses, and different water and soil salinities. The analyses of variance revealed that the interaction between seeding date and grass had a significant effect on both GDD50 and GDD95 and that GDD95 was significantly affected by the interaction between seeding date and water quality (Table 5; Fig. 3). Regardless of the seeding date, turfgrasses irrigated with potable water required more GDD to reach $95 \%$ cover than grasses irrigated with saline water (Fig. 3).

With the exception of perennial ryegrass, all cool-season grasses seeded in spring required more GDD50 and GDD95 than when seeded in fall (Table 7). Seeding date did not affect GDD required to reach $50 \%$ cover for perennial ryegrass (Table 7). In contrast to results obtained for cool-season grasses, warmseason bermudagrass and seashore paspalum seeded in spring required fewer GDD50 and GDD95 than when seeded in fall (Table 7). Shahba and Qian (2008) also reported that the number of GDD required by inland saltgrass [Disticlis spicata var. stricta (L.) Greene] to reach $80 \%$ coverage varied depending on establishment locations, seeding rates, and seeding dates. Our finding also concur with those of Schiavon et al. (2012) who reported that GDD based on soil temperature needed to establish bermudagrass and seashore paspalum differed depending on whether they were seeded in March or June and on whether they were irrigated with saline or potable water.

Our results indicate that seed coating does not negatively affect emergence or overall establishment of turfgrass seeds irrigated with saline water of a salinity level that matches reclaimed water. Although seed coating appeared to negatively affect early rates of establishment (less than 50\% cover), days needed to reach $95 \%$ groundcover did not differ between coated and uncoated seed regardless of seeding date or water quality. Irrigation in amounts greater than $\mathrm{ET}_{0}$ replacement may have compensated for the lower moisture retention of the uncoated seed.

Germination studies conducted in controlled environments appear to be poor predictors of turfgrass establishment under field conditions. Although our emergence results

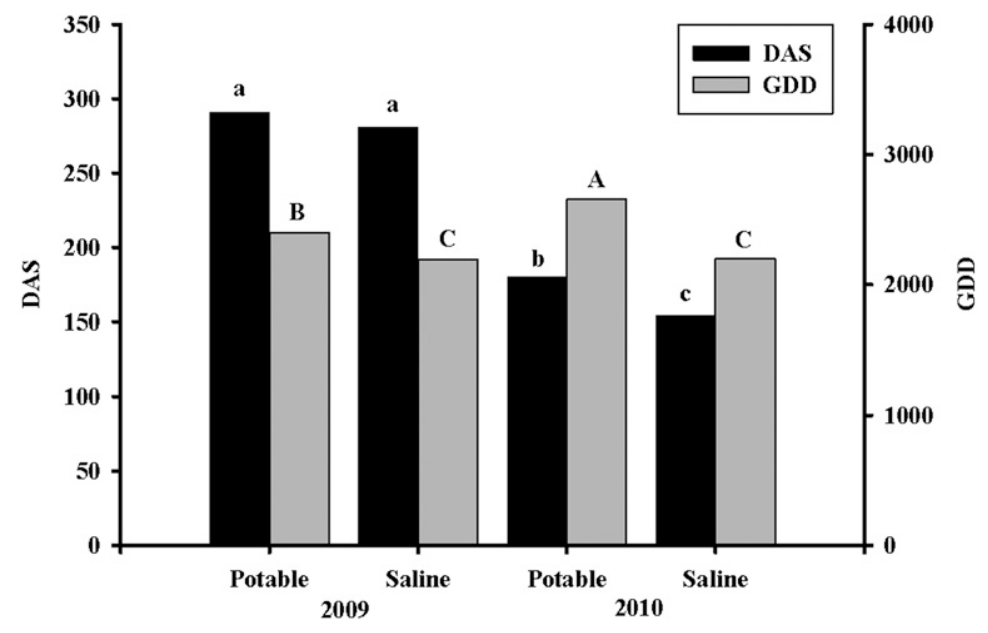

Fig. 3. Days after seeding (DAS) and growing degree-days (GDDs) to reach $95 \%$ groundcover of turfgrasses seeded either in fall (3 Sept. 2009) or in spring (15 Mar. 2010) and irrigated with either potable [electrical conductivity $(E C)=0.6 \mathrm{dS} \cdot \mathrm{m}^{-1}$ ] or saline $\left(E C=2.3 \mathrm{dS} \cdot \mathrm{m}^{-1}\right)$ water. Values are averaged over five grasses (bermudagrass, kentucky bluegrass, perennial ryegrass, seashore paspalum, and tall fescue), two seed treatments (coated and uncoated), and three replications. Bars followed by the same letters [separately for DAS (lower case letters) and GDD (upper case letters)] are not significantly from one another (Fisher's protected least significant difference, $\alpha=0.05$ ).

Table 7. Growing degree-days to reach $50 \%$ and $95 \%$ of groundcover (GDD50, GDD95). ${ }^{z}$

\begin{tabular}{|c|c|c|c|c|}
\hline \multirow[b]{3}{*}{ Grass } & \multicolumn{4}{|c|}{ Seeding date } \\
\hline & Fall 2009 & Spring 2010 & Fall 2009 & Spring 2010 \\
\hline & \multicolumn{2}{|c|}{ GDD50 } & \multicolumn{2}{|c|}{ GDD95 } \\
\hline Bermudagrass & $3142 a^{y}$ & $1731 \mathrm{c}$ & $3758 \mathrm{a}$ & $2277 \mathrm{~d}$ \\
\hline Kentucky bluegrass & $823 \mathrm{e}$ & $1754 \mathrm{c}$ & $959 \mathrm{f}$ & $2560 \mathrm{bc}$ \\
\hline Perennial ryegrass & $755 \mathrm{e}$ & $909 \mathrm{e}$ & $1048 \mathrm{f}$ & $2130 \mathrm{de}$ \\
\hline Seashore paspalum & $3144 \mathrm{a}$ & $2140 \mathrm{~b}$ & $3742 \mathrm{a}$ & $2802 \mathrm{~b}$ \\
\hline Tall fescue & $841 \mathrm{e}$ & $1200 \mathrm{~d}$ & $1974 \mathrm{e}$ & $2356 \mathrm{~cd}$ \\
\hline
\end{tabular}

${ }^{\mathrm{z}}$ Values represent an average of 12 data points and are pooled over two seed coating treatments (coated and uncoated), two water qualities (potable and saline), and three replicates.

${ }^{y}$ Values followed by the same letter (separately for GDD50 and GDD95) are not significantly different from one another (Fisher's protected least significant difference at $\alpha=0.05$ ). 
for fall-seeded warm- and cool-season grasses and for spring-seeded cool-season grasses are supported by growth chamber germination studies conducted by Serena et al. (2012), establishment rates of cool-season grasses differ. Although kentucky bluegrass had the lowest germination rates of all tested grasses in the growth chamber study, it established equally fast to perennial ryegrass in fall and to tall fescue in spring. More research is needed to investigate whether such results hold true over a wider range of turfgrass species and varieties and also in different climate zones.

Soil salinity measured over the course of this investigative period did not affect overall plant development. If irrigation during establishment is applied in amounts greater than $\mathrm{ET}_{0}$ replacement, treated effluent water can be used to establish turf areas for both fall and spring seeding. More field trials are needed to determine salinity thresholds under which establishment of cool- and warm-season grasses are negatively affected under varying climate conditions.

The GDD model did not account for the variation in temperatures between fall and spring seeding and produced different GDD for the two seeding periods. Higher air temperatures in late spring and early summer compared with late fall resulted in greater daily thermal units and comparatively faster growth for both warm- and cool-season grasses. Nonetheless, establishment of coolseason grasses at our test site (USDA plant hardiness zone 8) did not cease during the winter, and plots seeded in fall reached $95 \%$ coverage earlier in 2010 than plots seeded in spring. Our results indicate that fall seeding will result in earlier establishment in the subsequent year, which will have the turf area ready sooner for its intended purpose.

\section{Literature Cited}

Absorbent Technologies. 2006. Material safety data sheet ZEBA. 20 Apr. 2011. <http://www.zeba. com/pdfs/linked/20147_MSDS-All_Products. pdf>.

Allen, R.G., I.A. Walter, R.L. Elliott, T.A. Howell, D. Itenfisu, M.E. Jensen, and R.L. Snyder. 2005. The ASCE standardized reference evapotranspiration equation. American Society of Civil Engineers, Reston, VA.

Almansouri, M., J.M. Kinet, and S. Lutts. 2001. Effect of salt and osmotic stresses on germination in durum wheat (Triticum durum Desf.). Plant Soil 231:243-254.

Arends, C. 2007. Innovations in turfgrass. TurfNews 30:98-99.

Baskerville, G.L. and P.E. Emin. 1969. Rapid estimation of heat accumulation from maximum and minimum temperatures. Ecology 50:514-517.

Baxter, L. and L.J. Waters. 1986. Effect of a hydrophilic polymer seed coating on the field performance of sweet corn and cowpea. J. Amer. Soc. Hort. Sci. 111:31-34.

Berdhal, J.D. and R.E. Barker. 1980. Germination and emergence of Russian wildrye seed coated with hydrophilic materials. Agron. J. 72:10061008 .
Branham, B.E. and T.K. Danneberger. 1989. Growth suppression of 'Kenblue' kentucky bluegrass using plant growth regulators and degree-day accumulation. Agron. J. 81:749-752.

Busey, P. and B.J. Myers. 1979. Growth rates of turfgrasses propagated vegetatively. Agron. J. 71: 817-821.

Dudeck, A.E. and C.H. Peacock. 1985. Salinity effects on perennial ryegrass germination. HortScience 20:268-269.

Duncan, R.R., R.N. Carrow, and M.T. Huck. 2009. Turfgrass and landscape irrigation water quality-Assessment and management. CRC Press, Taylor and Francis Group, Boca Raton, FL.

Fiorio, F., S. Macolino, and B. Leinauer. 2012. Establishment and performance of bluegrass species and tall fescue under reduced-input maintenance in a temperate Mediterranean environment. HortTechnology 22:810-816.

Harivandi, M.A., J.D. Butler, and L. Wu. 1992. Salinity and turfgrass culture, p. 208-230. In: Waddison, D.V., et al. (ed.). Turfgrass Agron. Monogr. 32. ASA, CSSA, and SSSA, Madison, WI.

Harivandi, M.A., K.B. Marcum, and Y. Qian. 2008. Recycled, gray, and saline water irrigation for turfgrass. In: Beard, J.B. and M.P. Kenna (eds.). Water quality and quantity issues for turfgrasses in urban landscapes. Council for Agric. Sci. and Technol., Ames, IA.

Hendrick, R.M. and D.T. Mowry. 1953. U. S. Pat. No.2,651,883 (15 Sept.).

Huck, M., R.N. Carrow, and R.R. Duncan. 2000. Effluent water: Nightmare or dream come true? USGA Green Section Record March/April: $1-22$.

Ikemura, Y. 2003. Using digital image analysis to measure the nitrogen concentration of turfgrasses. MS thesis, Univ. of Arkansas, Fayetteville, AR.

Johnson, C.J., B. Leinauer, A.L. Ulery, D.E. Karcher, and R.M. Goss. 2007. Moderate salinity does not affect germination of several cool- and warm-season turfgrasses. Appl. Turf Sci. doi:10.1094/ATS-2007-0912-01RS.

Leinauer, B., M. Serena, and D. Singh. 2010. Seed coating and seeding rate effects on turfgrass germination and establishment. HortTechnology 20:179-183.

Loschinkohl, C. and M.J. Boehm. 2001. Composted biosolids incorporation improves turfgrass establishment on disturbed urban soil and reduces leaf rust severity. HortScience 36:790-794.

Marcum, K.B., S.J. Anderson, and M.C. Engelke. 1998. Salt gland and ion secretion: A salinity tolerance mechanism among five zoysiagrass species. Crop Sci. 38:806-810.

Newell, A.J. 1997. Effect of different seed treatments and coatings on the germination and establishment of four grass species. J. Sports Turf Res. Inst. 73:67-72.

NOAA. 1989. National weather service observing handbook no. 2. Cooperative station observations. NOAA. 19 Jan. 2012. <http://www.nws.noaa. gov/om/coop/Publications/coophandbook2.pdf>.

Peacock, C.H. and A.E. Dudeck. 1989. Influence of salinity on warm season turfgrass germination. The $6^{\text {th }}$ Int. Turf. Research Conf. Tokyo. p. 229231.

Qian, Y.L. and M.R. Suplick. 2001. Interactive effects of salinity and temperature on kentucky bluegrass and tall fescue seed germination. Intl. Turfgrass Soc. Res. J. 9:334-339.
Reicher, Z.J., C.S. Throssell, and D.V. Weisenberger. 2000. Date of seeding affects establishment of cool-season turfgrasses. HortScience 35:11661169.

Richardson, M.D. and K.W. Hignight. 2010. Seedling emergence of tall fescue and kentucky bluegrass, as affected by two seed coating treatments. HortTechnology 20:415-417.

Richardson, M.D., D.E. Karcher, and L.C. Purcell. 2001. Quantifying turfgrass cover using digital image analysis. Crop Sci. 41:1884-1888.

Schiavon, M., B. Leinauer, M. Serena, R. Sallenave, and B. Maier. 2012. Bermudagrass and seashore paspalum establishment from seed using differing irrigation methods and water qualities. Agron. J. 104:706-712.

Scott, J.M. 1989. Seed coatings and treatments and their effects on plant establishment. Adv. Agron. 42:43-83.

Serena, M., B. Leinauer, and S. Macolino. 2008. Planting date and water quality effects on the establishment of 2 warm-season grasses under sub-surface drip and sprinkler irrigation. 2008 ASA-CSSA-SSSA Annual Meeting Abstracts [CD-ROM computer file].

Serena, M., B. Leinauer, S. Macolino, and M. Gill. 2010. Germination of coated and uncoated turfgrass seed under saline conditions. $2^{\text {nd }}$ Europ. Turf. Conf., Angers, France, April 2010.

Serena, M., B. Leinauer, R. Sallenave, M. Schiavon, and B. Maier. 2012. Media selection and seed coating influence germination of turfgrasses under salinity. HortScience 47:116-119.

Shahba, M.A. and Y.L. Qian. 2008. Effect of seeding date, seeding rate, and seed treatments on saltgrass seed germination and establishment. Crop Sci. 48:2453-2458.

Sharples, G.C. 1981. Lettuce seed coating for enhanced seedling emergence. HortScience 16:661662.

Shaver, B.R., M.D. Richardson, J.H. McCalla, D.E. Karcher, and P.J. Berger. 2006. Dormant seeding bermudagrass cultivars in a transition-zone environment. Crop Sci. 46:1787-1792.

St. John, R., J. Fry, D. Bremer, and S. Keeley. 2009. Establishment rate and lateral spread of Festuca arundinacea cultivars. International Turfgrass Soc. Reserch J. 11:481-487.

Suplick-Ploense, M.R., Y.L. Qian, and J.C. Rear. 2002. Relative $\mathrm{NaCl}$ tolerance of kentucky bluegrass, Texas bluegrass and their hybrids. Crop Sci. 42:2025-2030.

Throssell, C.S., G.T. Lyman, M.E. Johnson, G.A. Stacey, and C.D. Brown. 2009. Golf course environmental profile measures water use, source, cost, quality, and management and conservation strategies. Applied Turfgrass Science. doi:10.1094/ATS-2009-0129-01-RS.

Unruh, J.B., R.E. Gaussoin, and S.C. Wiest. 1996. Basal growth temperature and growth rate constant of warm-season turfgrass species. Crop Sci. 36:997-999.

U.S. Salinity Laboratory Staff. 1954. Diagnosis and improvement of saline and alkali soils. USDA Handbook. 60. U.S. Gov. Print. Office, Washington, DC.

Wilhelm, S., S. Alshammary, and Y. Qian. 2010. Establishment, growth and irrigation requirements of kentucky bluegrass and tall fescue as influenced by two irrigation water sources. Research J. of Environ. Sci. 4:443-451.

Zhang, Q., S. Wang, and K. Rue. 2011. Salinity tolerance of 12 turfgrasses in three germination media. HortScience 46:651-654. 